\title{
3,3',5,5'-Tetramethoxybenzoin: a forgotten photolabile protecting group
}

\author{
Dario Bragagnolo $^{1}\left[\right.$ (D) Christian G. Bochet ${ }^{1}$ (])
}

Received: 11 October 2021 / Accepted: 28 November 2021 / Published online: 14 January 2022

(c) The Author(s), under exclusive licence to European Photochemistry Association, European Society for Photobiology 2021

\begin{abstract}
Although reported several decades ago, 3,3',5,5'-tetramethoxybenzoin esters have not been used as a common photolabile protecting group, contrary to their unsymmetrical 3',5'-dimethoxybenzoin analogues. While the properties of the latter are superior, their tedious synthesis and chemical instability represent a drawback. In this article, we describe a reliable synthetic access to the symmetrical tetramethoxybenzoin derivatives, and show that their photochemical behaviour remain interesting, in particular chromatically orthogonality with respect to nitroveratryl esters.
\end{abstract}

Keywords Photochemistry $\cdot$ Protecting groups $\cdot$ Benzoin condensation $\cdot$ Quantum yield $\cdot$ Caged compounds

\section{Introduction}

Photolabile protecting groups have proven to be valuable tools in many fields, ranging from material science to biology, and of course including organic synthesis [1,2]. Over the years, many different groups were developed and optimized for a specific property, such as most sensitive wavelength [3], speed [4], orthogonality [5-9], reliability, etc. In the currently available arsenal, a particular family of groups have emerged as one of the most popular, mainly by its robustness with respect to experimental conditions: the nitroveratryl (NV) derivatives $\mathbf{3}$ (commonly used as an oxycarbonyl derivative, NVOC) [10]. It is quite interesting to note that experimental convenience supersedes the fact that it is neither very fast, nor having a high quantum yield. On the other hand, 3',5'-dimethoxybenzoin derivatives (DMB 2, Scheme 1) show a quite high photolysis quantum yield $(\phi=0.644$ in MeCN) [11], and are chromatically orthogonal with NVOC derivatives $[12,13]$, yet they are only rarely used [1, 14-16]. One of the reasons for its underutilization is the quite delicate synthesis, requiring the addition of a Grignard reagent to a silylated cyanohydrin [17]. A more recent synthesis was developed, involving an umpolung reaction with a dithiane $[18,19]$, but the latter deprotection

Christian G. Bochet

christian.bochet@unifr.ch

1 Department of Chemistry, University of Fribourg, 9 chemin du Musée, 1700 Fribourg, Switzerland (under oxidative conditions) proved extremely sensitive to the quality of the reagents. In our own hands, despite the fact that we could reproduce the originally published yields, the reaction failed in an unpredictable way sometimes on largescale batches [6]. A symmetrical analogue of this benzoin, the 3,3',5,5'-tetramethoxybenzoin 1 (TMB) would represent a much more easily available alternative, as a regular benzoin condensation would in principle afford it in a single step [12]. This triggered some interest in the late 80's and 90 's, but the reaction was either found unreliable too [13], or required additional additives [20,21]. In this technical note, we report both a reliable synthetic access and a brief study on its photochemical properties. These suggest that TMB represents an attractive replacement of DMB as a photolabile protecting group.

\section{Results and discussion}

a) Preparation

Benzoin 1 was prepared by a classical benzoin condensation in refluxing ethanol-water $(6: 1, \mathrm{v} / \mathrm{v})$, using 10 mol-\% of sodium cyanide as a catalyst (scheme 2). Purification by column chromatography gave the pure benzoin. The use of more catalyst (40 mol-\%) was detrimental to the yield. Various ester derivatives were prepared from their acid chloride precursors in standard conditions (triethylamine, DMAP) at room temperature (scheme 3). 
<smiles>COc1cc(OC)cc(C(=O)C(OC(C)=O)c2cc(OC)cc(OC)c2)c1</smiles>

1

this work<smiles>COc1cc(C=O)cc(OC)c1</smiles><smiles>COc1cc(OC)cc(C(C#N)C(OC(C)=O)c2cc(OC)cc(OC)c2)c1</smiles>

2

refs. 18,19$]$<smiles>COc1cc(C=O)cc(OC)c1</smiles>

Scheme 1. Benzoin-type photolabile protecting groups<smiles>COc1cc(C=O)cc(C(=O)C(O)c2cc(OC)cc(OC)c2)c1</smiles>

Scheme 2. Preparation of benzoin 1

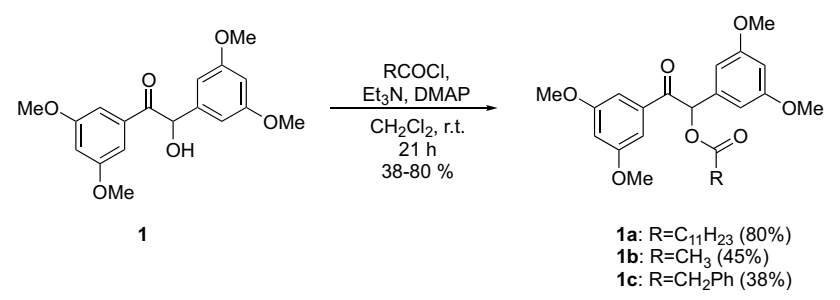

Scheme 3. Preparation of esters 1a-c

b) Photochemical properties

Contrary to 3',5'-dimethoxybenzoin acetate (2b), with an absorption maximum below $250 \mathrm{~nm}$, tetramethoxybenzoin 1a-c esters typically have a $\lambda_{\max }$ around $270 \mathrm{~nm}$ (268 nm for acetate 1b) (Fig. 1). This may simplify experimental conditions, as LED UV sources, now commonly used, are considerably less expensive at this wavelength. In this study, $265 \mathrm{~nm}$ LED's were used.

The quantum yield of photolysis of ester $1 \mathbf{a}$ was measured in acetonitrile, $\phi=0.17$ (average of three runs, standard deviation 0.033). This is perfectly in line with the observation of Corrie and Trentham [13], quoting "four-fold less conversion" with respect to Sheehan's reported quantum yield in acetonitrile ( $\phi=0.644 \pm 0.029)$ for acetate $\mathbf{2 b}$. [11] The expected released product of the photolysis of $\mathbf{1 b}$ being the volatile acetic acid, we repeated the reaction with lauric ester 1a, and isolated $96 \%$ of lauric acid by acid/base extraction, together with variable amounts of tetramethoxybenzofuran 4 (Scheme 4). The latter is not photochemically stable, and further decomposition products were also detected (but not isolated). Its formation presumably arises from a similar mechanism as seen for the related derivatives of 2 . [1]

To probe its chromatic orthogonality with respect to nitroveratryl derivatives, a $3 \mathrm{mM}$ mixture of $\mathbf{1 a}$ and $\mathbf{3 b}$ in acetonitrile was photolyzed at $265 \mathrm{~nm}$ with UV-LED's (estimated bandwidth $10 \mathrm{~nm}$ ). After $85 \mathrm{~min}, 83 \%$ of $\mathbf{1 a}$ was photolyzed, whereas $83 \%$ of acetate $\mathbf{3 b}$ remained intact (Scheme 5). The same experiment was repeated at $405 \mathrm{~nm}$. After $88 \mathrm{~h}, \mathbf{1 a}$ remained fully intact, whereas $64 \%$ of $\mathbf{3 b}$ reacted. Despite the very long reaction time, reflecting the inertness of the tetramethoxybenzoin

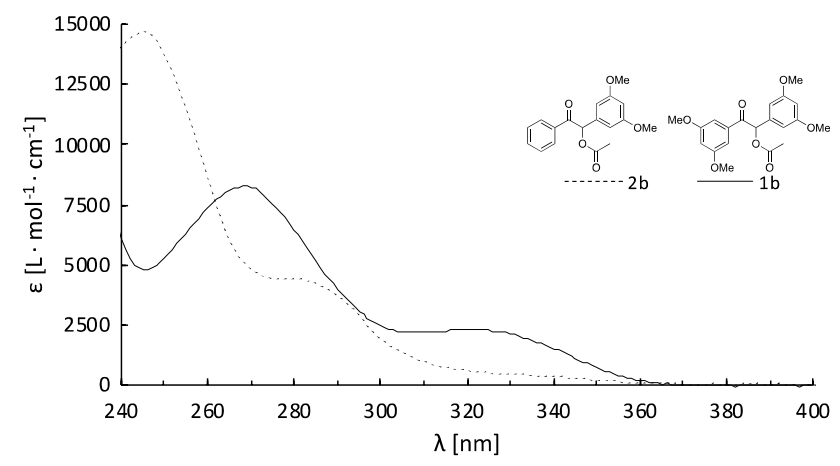

Fig. 1 UV-Vis spectrum of $\mathbf{1 b}$ and $\mathbf{2 b}$ 


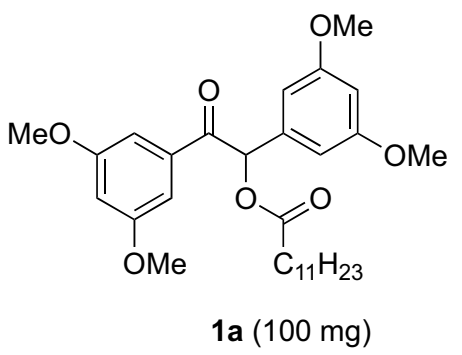

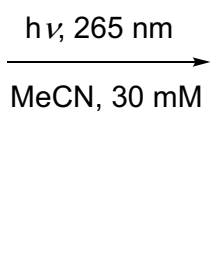<smiles>COc1cc(OC)cc(-c2cc3cc(OC)cc(OC)c3o2)c1</smiles>

$96 \%$

Scheme 4. Photolysis of ester 1a<smiles>CCCCCCCCCCCCCCCCCCC(=O)OC(C(=O)c1cc(OC)cc(OC)c1)c1cc(OC)cc(OC)c1</smiles>

$1 a$<smiles>COc1cc(COC(C)=O)c([N+](=O)[O-])cc1OC</smiles>

$3 b$

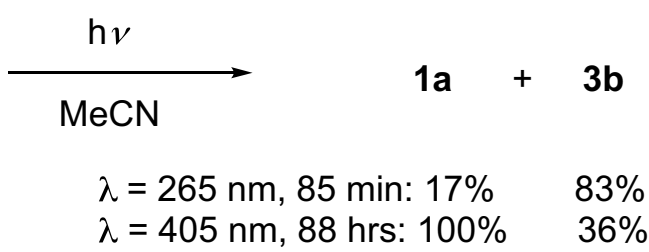

$\mathrm{h} v, 265 \mathrm{~nm}$
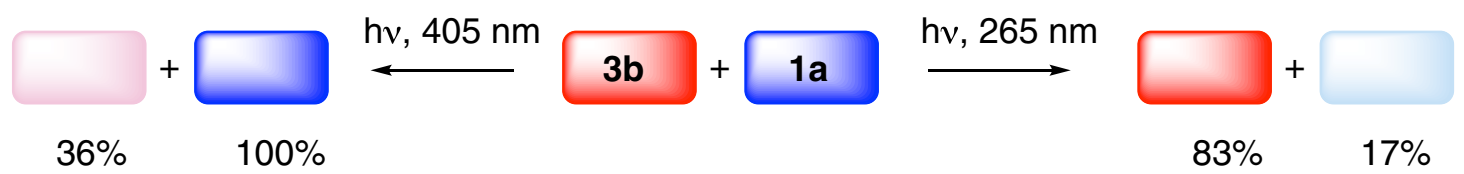

Scheme 5. Chromatic orthogonality of esters $\mathbf{1}$ and $\mathbf{3}$

esters and the low quantum efficiency of the nitroveratryl esters, both groups are unambiguously chromatically orthogonal, in a similar way as our original pair DMB/ $\mathrm{NV}$ pair [5, 6]. By shortening the wavelength from 405 to $365 \mathrm{~nm}$, some orthogonality was retained, but to a more modest extent (after 11 min: 70\% of 1a was intact and $71 \%$ of $\mathbf{3 b}$ had reacted).

\section{Conclusion}

In conclusion, we can observe that TMB is significantly easier to prepare, and its photochemical performances, although slightly degraded with respect to its DMB parent, remain in a reasonable range and thus make it a good substitute. A particularly interesting feature is its chromatic orthogonality with nitroveratryl esters.

\section{Experimental part}

\subsection{Synthetic procedures}

\subsubsection{3,3' ${ }^{\prime}, 5,5^{\prime}$-tetramethoxybenzoin 1}

A solution of sodium cyanide $(33.2 \mathrm{mg}, 0.110$ equiv., $677 \mu \mathrm{mol})$ in water $(0.5 \mathrm{~mL})$ was added to a hot solution of 3,5-dimethoxybenzaldehyde (1020.4 mg, 1 equiv., $6.1403 \mathrm{mmol})$ in EtOH $(3.0 \mathrm{~mL})$, which was then heated to reflux for $25 \mathrm{~h}$. After the solution was allowed to cool down to room temperature a sat. $\mathrm{NaHCO}_{3}$ solution was added. The mixture was extracted four times with $\mathrm{Et}_{2} \mathrm{O}$. The organic layers were combined, dried over $\mathrm{Na}_{2} \mathrm{SO}_{4}$ and concentrated under reduced pressure, yielding an orange crude product. Purification by column chromatography (silica gel; EtOAc:n-pentane 1:9 to 1:4) yielded 1,2-bis(3,5-dimethoxyphenyl)-2-hydroxyethan-1-one 1 (599.6 mg, $1.804 \mathrm{mmol}, 59 \%)$ as an orange oil that solidified over time turning into a yellow solid. $\lambda(\mathrm{MeCN}) / \mathrm{nm}$ 268 and $319\left(\varepsilon / 10^{3} \cdot \mathrm{L} \cdot \mathrm{mol}^{-1} \cdot \mathrm{cm}^{-1} 8.1\right.$ and 2.4$) .{ }^{1} \mathbf{H}-$ NMR $\left(400 \mathrm{MHz}, \mathrm{CDCl}_{3}\right): \delta(\mathrm{ppm}) 3.75(6 \mathrm{H}, \mathrm{s}), 3.78(6 \mathrm{H}$, 
s), $4.45(1 \mathrm{H}$, br. S.), $5.80(1 \mathrm{H}, \mathrm{s}), 6.37(1 \mathrm{H}, \mathrm{t}, J=2.3 \mathrm{~Hz})$, $6.48(2 \mathrm{H}, \mathrm{d}, J=2.3 \mathrm{~Hz}), 6.62(1 \mathrm{H}, \mathrm{t}, J=2.3 \mathrm{~Hz}), 7.07$ $(2 \mathrm{H}, \mathrm{d}, J=2.3 \mathrm{~Hz}) \cdot{ }^{13} \mathrm{C}-\mathbf{N M R}\left(101 \mathrm{MHz}, \mathrm{CDCl}_{3}\right): \delta$ (ppm) 55.4, 55.5, 76.3, 77.2, 100.5, 105.8, 106.4, 106.9, 135.2, 141.1, 160.8, 161.3, 198.5. FT-IR (golden gate, $600-4000 \mathrm{~cm}^{-1}$ ) 3481, 3016, 2974, 2938, 2837, 1669, $1592,1454,1427,1355,1301,1293,1268,1229,1208$, 1200, 1156, 1085, 1060, 1048, 1014, 947, 924, 887, 849, 842, 816, 789, 731, 703, 676, 655, 634. HR-MS (ESI) for $\left(\mathrm{M}-\mathrm{Na}^{+}\right)$: calcd 355.1152, found 355.1133.

\subsubsection{Lauryl ester 1a}

Benzoin 1 (0.99 g, 1 equiv., $3.0 \mathrm{mmol})$ and $N, N$-dimethylpyridin-4-amine $(0.124 \mathrm{~g}, 0.34$ equiv., $1.01 \mathrm{mmol})$ were dissolved in anhydrous $\mathrm{CH}_{2} \mathrm{Cl}_{2}(2 \mathrm{~mL})$ and cooled with an icebath. Triethylamine $(0.30 \mathrm{~g}, 0.42 \mathrm{~mL}, 1.0$ equiv., $3.0 \mathrm{mmol})$ and later dodecanoyl chloride $(0.72 \mathrm{~g}, 0.76 \mathrm{~mL}$, 1.1 equiv., $3.3 \mathrm{mmol}$ ) were added dropwise to the solution. The reaction was left to slowly warm up to room temperature overnight. After $22 \mathrm{~h}$, EtOAc was added. The organic phase was washed three times with $1 \mathrm{M} \mathrm{HCl}$ and then water and a sat. $\mathrm{NaHCO}_{3}$ solution. The organic phase was concentrated under reduced pressure, and purified by reverse-phase chromatography $(\mathrm{C} 18,20-100 \% \mathrm{MeCN}$ in water), yielding $1 \mathrm{a}(1.2205 \mathrm{~g}, 2.3715 \mathrm{mmol}, 80 \%)$ as a yellow oil that solidified over time turning into a white/ yellowish solid. $\lambda(\mathrm{MeCN}) / \mathrm{nm} 268$ and $322\left(\varepsilon / 10^{3} \cdot \mathrm{L}\right.$. $\mathrm{mol}^{-1} \cdot \mathrm{cm}^{-1} 8.8$ and 2.5$)$. ${ }^{1} \mathbf{H}-\mathbf{N M R}\left(400 \mathrm{MHz}, \mathrm{CDCl}_{3}\right)$ : $\delta(\mathrm{ppm}) 0.88(3 \mathrm{H}, \mathrm{t}, J=6.6 \mathrm{~Hz}), 1.12-1.42(17 \mathrm{H}, \mathrm{m})$, $1.68(2 \mathrm{H}$, quin, $J=7.3 \mathrm{~Hz}), 2.27-2.72(2 \mathrm{H}, \mathrm{m}), 3.77(6$ $\mathrm{H}, \mathrm{s}), 3.79(6 \mathrm{H}, \mathrm{s}), 6.42(1 \mathrm{H}, \mathrm{t}, J=2.3 \mathrm{~Hz}), 6.53-6.67$ (3 H, m), $6.69(1 \mathrm{H}, \mathrm{s}), 7.09(2 \mathrm{H}, \mathrm{d}, J=2.2 \mathrm{~Hz}) .{ }^{13} \mathbf{C}-\mathbf{N M R}$ $\left(101 \mathrm{MHz}, \mathrm{CDCl}_{3}\right): \delta(\mathrm{ppm}) 14.1,22.7,24.8,29.1,29.26$, 29.32, 29.4, 29.6, 31.9, 34.0, 55.4, 55.5, 77.2, 77.5, 101.2, 106.0, 106.56, 106.58, 135.7, 136.4, 160.8, 161.2, 173.3, 193.4. FT-IR (golden gate, 600-4000 cm $\mathrm{cm}^{-1}$ ) 2998, 2953, 2923, 2852, 1728, 1698, 1605, 1594, 1462, 1427, 1380, 1357, 1333, 1316, 1296, 1260, 1206, 1192, 1154, 1066, 1043, 1010, 972, 946, 931, 877, 849, 827, 787, 757, 723, 698, 671, 644, 630. HR-MS (ESI) for $\left(\mathrm{M}-\mathrm{Na}^{+}\right)$: calcd 515.3003, found 515.2992.

\subsubsection{Acetate $1 \mathrm{~b}$}

Benzoin 1 (540.3 mg, 1 equiv., $1.626 \mathrm{mmol}$ ) and $N, N$-dimethylpyridin-4-amine ( $24.7 \mathrm{mg}, 0.124$ equiv., $202 \mu \mathrm{mol}$ ) were dissolved in anhydrous $\mathrm{CH}_{2} \mathrm{Cl}_{2}(5.0 \mathrm{~mL})$ and cooled with an icebath. Triethylamine $(0.17 \mathrm{mg}, 0.23 \mathrm{~mL}, 1.0$ equiv., $1.7 \mathrm{mmol})$ and later acetyl chloride $(0.14 \mathrm{~g}, 0.13 \mathrm{~mL}, 1.1$ equiv., $1.8 \mathrm{mmol}$ ) were added dropwise to the solution. The reaction was allowed to warm up slowly to room temperature overnight. After $23 \mathrm{~h}$, EtOAc was added and the organic phase was washed three times with $1 \mathrm{M} \mathrm{HCl}$, followed by water and brine. The organic phase was dried over $\mathrm{Na}_{2} \mathrm{SO}_{4}$ and concentrated under reduced pressure. The product was purified by reverse-phase chromatography $(\mathrm{C} 18,20-100 \%$ $\mathrm{MeCN}$ in water $)$ yielding $\mathbf{1 b}(0.2756 \mathrm{~g}, 736.1 \mu \mathrm{mol}, 45 \%)$ as an off-white solid. $\lambda(\mathrm{MeCN}) / \mathrm{nm} 268$ and $320\left(\varepsilon / 10^{3} \cdot \mathrm{L}\right.$ $\cdot \mathrm{mol}^{-1} \cdot \mathrm{cm}^{-1} 8.3$ and 2.3$) .{ }^{\mathbf{1}} \mathbf{H}-\mathbf{N M R}\left(400 \mathrm{MHz}, \mathrm{CDCl}_{3}\right)$ : $\delta(\mathrm{ppm}) 2.22(3 \mathrm{H}, \mathrm{s}), 3.77(6 \mathrm{H}, \mathrm{s}), 3.79(6 \mathrm{H}, \mathrm{s}), 6.43(1$ $\mathrm{H}, \mathrm{t}, J=2.3 \mathrm{~Hz}), 6.52-6.65(3 \mathrm{H}, \mathrm{m}), 6.69(1 \mathrm{H}, \mathrm{s}), 7.08(2$ $\mathrm{H}, \mathrm{d}, J=2.2 \mathrm{~Hz}) \cdot{ }^{13} \mathbf{C}-\mathbf{N M R}\left(101 \mathrm{MHz}, \mathrm{CDCl}_{3}\right): \delta(\mathrm{ppm})$ 20.8, 55.4, 55.5, 77.2, 77.8, 101.3, 106.0, 106.59, 106.64, 135.6, 136.3, 160.8, 161.2, 170.4, 193.2. FT-IR (golden gate, 600-4000 cm ${ }^{-1}$ ) 3012, 2960, 2934, 2841, 1727, 1691, 1592, $1457,1425,1373,1361,1347,1301,1284,1257,1241,1206$, 1153, 1063, 1045, 1016, 1005, 991, 964, 937, 925, 894, 848, 836, 786, 758, 700, 681, 645, 637, 604. HR-MS (ESI) for $\left(\mathrm{M}-\mathrm{Na}^{+}\right)$: calcd 397.1258, found 397.1242.

\subsubsection{Phenacyl ester 1c}

Benzoin 1 (511.7 mg, 1 equiv., $1.540 \mathrm{mmol})$ and $N, N$ dimethylpyridin-4-amine ( $81.5 \mathrm{mg}, 0.433$ equiv., $667 \mu \mathrm{mol})$ were dissolved in anhydrous $\mathrm{CH}_{2} \mathrm{Cl}_{2}(5.0 \mathrm{~mL})$ and cooled with an icebath. Triethylamine (18 mg, $25 \mu \mathrm{L}$, 0.12 equiv., $0.18 \mathrm{mmol}$ ) and later phenylacetyl chloride (267 mg, $230 \mu \mathrm{L}, 1.12$ equiv., $1.73 \mathrm{mmol}$ ) were added dropwise to the solution. The reaction was allowed to warm up slowly to room temperature overnight. After $29 \mathrm{~h}$, EtOAc was added and the organic phase was washed three times with $1 \mathrm{M} \mathrm{HCl}$ followed by water and brine. The organic phase was dried over $\mathrm{Na}_{2} \mathrm{SO}_{4}$ and concentrated under reduced pressure. The product was purified by reverse-phase chromatography $(\mathrm{C} 18,20-100 \% \mathrm{MeCN}$ in water) yielding 1c $(0.2629 \mathrm{~g}, 583.6 \mu \mathrm{mol}, 38 \%)$ as a yellow oil. $\lambda(\mathrm{MeCN}) / \mathrm{nm} 269$ and $317\left(\varepsilon / 10^{3} \cdot \mathrm{L} \cdot \mathrm{mol}^{-1}\right.$. $\mathrm{cm}^{-1} 8.6$ and 2.4). ${ }^{1} \mathbf{H}-\mathbf{N M R}\left(400 \mathrm{MHz}, \mathrm{CD}_{3} \mathrm{CN}\right): \delta$ (ppm) $3.65-3.89(15 \mathrm{H}, \mathrm{m}), 6.46(1 \mathrm{H}, \mathrm{t}, J=2.3 \mathrm{~Hz}), 6.58(2$ $\mathrm{H}, \mathrm{d}, J=2.3 \mathrm{~Hz}), 6.68(1 \mathrm{H}, \mathrm{t}, J=2.3 \mathrm{~Hz}), 6.80(1 \mathrm{H}, \mathrm{s})$, $7.06(2 \mathrm{H}, \mathrm{d}, J=2.2 \mathrm{~Hz}), 7.20-7.50(5 \mathrm{H}, \mathrm{m}) .{ }^{13} \mathbf{C}-\mathbf{N M R}$ $\left(101 \mathrm{MHz}, \mathrm{CD}_{3} \mathrm{CN}\right): \delta(\mathrm{ppm}) 41.3,56.3,56.5,78.9,101.7$, 106.7, 107.3, 107.6, 128.1, 129.6, 130.5, 135.3, 136.9, 137.5, 162.2, 162.4, 172.0, 194.2. FT-IR (golden gate, 600-4000 $\mathrm{cm}^{-1}$ ) 3091, 3064, 3004, 2961, 2939, 2839, 1737, 1696, 1592, 1455, 1427, 1348, 1298, 1250, 1204, 1151, 1061, 1041, 1005, 991, 977, 926, 843, 785, 745,

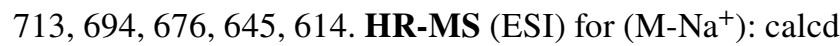
473.1571, found 473.1551 .

\subsubsection{Benzofuran 4}

A solution of $\mathbf{1 b}(101.9 \mathrm{mg}, 1$ equiv., $272.2 \mu \mathrm{mol})$ in $\mathrm{MeCN}(7 \mathrm{~mL})$ was irradiated in a Rayonet photoreactor 
equipped with $16254 \mathrm{~nm}$ tubes for $10 \mathrm{~h}$. The solvent and volatiles were removed in vacuo and the crude mixture was purified by reverse-phase chromatography $(\mathrm{C} 18,20-100 \%$ $\mathrm{MeCN}$ in water) yielding $4(26.3 \mathrm{mg}, 83.7 \mu \mathrm{mol}, 31 \%)$ as a brown solid. $\lambda(\mathrm{MeCN}) / \mathrm{nm} 217$ and $300\left(\varepsilon / 10^{3} \cdot \mathrm{L} \cdot \mathrm{mol}^{-1}\right.$ . $\mathrm{cm}^{-1} 31.7$ and 25.4). ${ }^{1} \mathbf{H}$-NMR $\left(400 \mathrm{MHz}, \mathrm{CDCl}_{3}\right): \delta$ (ppm) $3.86(3 \mathrm{H}, \mathrm{s}), 3.88(6 \mathrm{H}, \mathrm{s}), 4.02(3 \mathrm{H}, \mathrm{s}), 6.39-6.60$ $(2 \mathrm{H}, \mathrm{m}), 6.63(1 \mathrm{H}, \mathrm{d}, J=2.2 \mathrm{~Hz}), 6.94(1 \mathrm{H}, \mathrm{s}), 7.02(2$ $\mathrm{H}, \mathrm{d}, J=2.3 \mathrm{~Hz}) .{ }^{13} \mathbf{C}-\mathbf{N M R}\left(101 \mathrm{MHz}, \mathrm{CDCl}_{3}\right): \delta(\mathrm{ppm})$ 55.5, 55.9, 56.1, 77.2, 94.5, 97.4, 101.0, 102.4, 103.1, $130.4,132.2,139.5,145.5,156.4,156.9,161.1$

\subsection{Uncaging and isolation of lauric acid}

A solution of 1a (106.4 mg, 1 equiv., $206.7 \mu \mathrm{mol})$ in MeCN ( $7 \mathrm{~mL})$ was irradiated in a Rayonet photoreactor equipped with $16254 \mathrm{~nm}$ tubes for $4 \mathrm{~h}$. The solution was concentrated under reduced pressure. The crude mixture was dissolved in $\mathrm{CHCl}_{3}$, extracted three times with a $\mathrm{NaOH}$ solution. The combined aqueous layers were acidified with $1 \mathrm{M} \mathrm{HCl}$. The acidic solution was extracted three times with $\mathrm{CHCl}_{3}$. Evaporation of the solvent yielded a brown/white solid residue, which was dissolved in $\mathrm{CHCl}_{3}$ and filtered. Concentration under reduced pressure yielded dodecanoic acid (39.9 mg, $199 \mu \mathrm{mol}, 96 \%)$.

Supplementary Information The online version contains supplementary material available at https://doi.org/10.1007/s43630-021-00150-7.

Author contributions $\mathrm{CB}$ and $\mathrm{DB}$ designed the experiments. DB carried out the experimental work. $\mathrm{CB}$ wrote the manuscript.

Funding The financial support of the University of Fribourg is gratefully acknowledged.

Availability of data and materials Supplementary information containing spectra and other data are available.

\section{Declarations}

Conflict of interest The authors declare that they have no conflict of interest.

\section{References}

1. Klán, P., Šolomek, T., Bochet, C. G., Blanc, A., Givens, R., Rubina, M., Popik, V., Kostikov, A., \& Wirz, J. (2013). Photoremovable protecting groups in chemistry and biology: reaction mechanisms and efficacy. Chemical Reviews, 113(1), 119-191. https://doi.org/10.1021/cr300177k

2. Bochet, C. G. (2002). Photolabile protecting groups and linkers. Journal of the Chemical Society, Perkin Transactions 1, , 125-142. https://doi.org/10.1039/B009522M

3. Weinstain, R., Slanina, T., Kand, D., \& Klán, P. (2020). Visible-to-NIR-light activated release: from small molecules to nanomaterials. Chemical Reviews. https://doi.org/10.1021/acs. chemrev.0c00663

4. Givens, R. S., Jung, A., Park, C.-H., Weber, J., \& Bartlett, W. (1997). New photoactivated protecting groups. 7. p -Hydroxyphenacyl: a phototrigger for excitatory amino acids and peptides. Journal of the American Chemical Society, 119(35), 8369-8370. https://doi.org/10.1021/ja971331n

5. Bochet, C. G. (2001). Orthogonal photolysis of protecting groups. Angewandte Chemie International Edition, 40(11), 2071-2073.

6. Blanc, A., \& Bochet, C. G. (2002). Wavelength-controlled orthogonal photolysis of protecting groups. Journal of Organic Chemistry, 67(16), 5567-5577. https://doi.org/10.1021/jo025837m

7. Bochet, C. G. (2004). Chromatic orthogonality in organic synthesis. Synlett, 13, 2268-2274. https://doi.org/10. 1055/s-2004-832848

8. Bochet, C. G. (2021). Two decades of chromatic orthogonality. Israel Journal of Chemistry, 61(7-8), 486-495.

9. Hansen, M. J., Velema, W. A., Lerch, M. M., Szymański, W., \& Feringa, B. L. (2015). Wavelength-selective cleavage of photoprotecting groups: strategies and applications in dynamic systems. Chemical Society Reviews, 44(11), 3358-3377. https://doi.org/10. 1039/C5CS00118H

10. Patchornik, A., Amit, B., \& Woodward, R. B. (1970). Photosensitive protecting groups. Journal of the American Chemical Society, 91(21), 6333-6335.

11. Sheehan, J. C., Wilson, R. M., \& Oxford, A. W. (1971). The photolysis of methoxy-substituted benzoin esters. A photosensitive protecting group for carboxylic acids. Journal of the American Chemical Society, 93(26), 7222-7228.

12. Sheehan, J. C., \& Wilson, R. M. (1964). Photolysis of desyl compounds. A new photolytic cyclization. Journal of the American Chemical Society, 86(23), 5277-5281. https://doi.org/10.1021/ ja01077a046

13. Corrie, J. E. T., \& Trentham, D. R. (1992). Synthetic, mechanistic and photochemical studies of phosphate esters of substituted benzoins. Journal of the Chemical Society, Perkin Transactions 1, 2409-2417. https://doi.org/10.1039/p19920002409

14. Pirrung, M. C., \& Huang, C.-Y. (1995). Photochemical deprotection of 3',5'-dimethoxybenzoin (DMB) carbamates derived from secondary amines. Tetrahedron Letters, 36(33), 5883-5884. https://doi.org/10.1016/0040-4039(95)01184-J

15. Pirrung, M. C., \& Bradley, J.-C. (1995). Dimethoxybenzoin carbonates: photochemically-removable alcohol protecting groups suitable for phosphoramidite-based DNA synthesis. Journal of Organic Chemistry, 60(5), 1116-1117. https://doi.org/10.1021/ jo00110a011

16. Pirrung, M. C., \& Bradley, J.-C. (1995). Comparison of methods for photochemical phosphoramidite-based DNA synthesis. Journal of Organic Chemistry, 60(20), 6270-6276. https://doi.org/10. 1021/jo00125a010

17. Pirrung, M. C., \& Shuey, S. W. (1994). Photoremovable protecting groups for phosphorylation of chiral alcohols. Asymmetric synthesis of phosphotriesters of (-)-3',5'-dimethoxybenzoin. The Journal of Organic Chemistry, 59(14), 3890-3897. https://doi. org/10.1021/jo00093a021

18. Lee, H. B., \& Balasubramanian, S. (1999). Studies on a dithianeprotected benzoin photolabile safety catch linker for solid-phase synthesis. Journal of Organic Chemistry, 64(10), 3454-3460. https://doi.org/10.1021/jo981987e

19. Cano, M., Ladlow, M., \& Balasubramanian, S. (2002). Practical synthesis of a dithiane-protected 3',5'-dialkoxybenzoin photolabile safety-catch linker for solid-phase organic synthesis. Journal of Organic Chemistry, 67(1), 129-135. https://doi.org/10.1021/ jo010703e

20. Cameron, J. F., Willson, C. G., \& Frechet, J. M. J. (1997). Photogeneration of amines from $\alpha$-keto carbamates: photochemical 
studies. Journal of the American Chemical Society, 118(51), 12925-12937. https://doi.org/10.1021/ja954339a

21. Arifin, K., Minggu, L. J., Daud, W. R. W., Yamin, B. M., Daik, R., \& Kassim, M. B. (2014). Synthesis, structure and theoretical investigation into a homoleptic tris(dithiolene) tungsten. Spectrochimica Acta Part A: Molecular and Biomolecular Spectroscopy, 120, 208-215. https://doi.org/10.1016/j.saa.2013.09.069 